\title{
RESPONSIBILITY AND TECHNICS IN LEVINAS AND JONAS
}

\author{
TWO STRATEGIES IN RESPONSE TO THE DISORIENTATION OF ETHICS IN THE MODERN WORLD
}

Ernst Wolff

In this essay I undertake a comparative study on the work of Emmanuel Levinas and Hans Jonas. ${ }^{1}$ It is possible to approach such a comparison by discussing their philosophies primarily from the perspective of the influence of their Judaic heritage, in which elements of monotheism and a concomitant religious ethics would be the most central parts. What I present does not aim to reject such a perspective, but instead provides another perspective, which could be considered to put comparisons from the former perspective in a different light. I chose to pursue this line of enquiry because, regarding the issue of ethics, at the center of both Levinas and Jonas's philosophical concern is the concession that, first, the non-religious philosophical diagnosis of contemporary culture is to be taken very seriously and, second, that if one is to respond to this crisis, it has to be done, as far as possible, in terms of that secular philosophy. In other words, I would argue that, for both our authors, if one wishes to contemplate what they, as philosophers, say about God and ethics, this enquiry can be undertaken successfully only if one follows them in accepting the existence of the crisis which has been called nihilism or the "death of God." The ethics of responsibility of which both speak (in their respective ways) cannot be typified as simply a derivative of a monotheism drawn into philosophy - their ethics was formulated in response to their recognition of the problem of the death of God. This means that both philosophers implicitly propose to their readers as a criterion for the success of their work not the fidelity with which they can speak in Greek about the Hebrew God, but the success with which they as philosophers can respond to the crisis of the death of God, that is, of nihilism. ${ }^{2}$

PHILOSOPHY TODAY
This perspective on Levinas and Jonas unfolds neatly when one starts reading them, not, in the first place, from the perspective of their Judaic convictions, but from the perspective of their acknowledged indebtedness to Heidegger. ${ }^{3}$ Both Levinas and Jonas were won over very early to the Heideggerian perspective on human existence as originally care. ${ }^{4}$ The analysis of Dasein as a non-consciousness-centered access to our being-in-the-world consists of two aspects that are crucial to both Levinas and Jonas: to begin with, the openness of human existence to the world is one of practice, of I can, before I think; and next, all meaning is derived from this fact. In Heideggerian pragmatism, ${ }^{5}$ the range of human action and the range of meaning are co-original. But from this twin source, contemporary culture develops in two important directions that pose different kinds of problem to human existence. On the one hand, the range of action is augmented and changed in nature by the new technical means. On the other hand, there is increasing recognition of the conviction that a variety of actions, whose meaning forms within culturally specific contexts, do not allow for a unifying point of reference that would enable judgment to be passed on the value of these meanings; this is to say that a window is opened on the so-called death of God.

For philosophers who have been influenced by Heidegger in some way, thinking about ethics would have to include responding to a proliferation of meanings that lack any point of reference for their validity. In the contemporary world, they would have to be open to reflecting on the relevance of a "resuscitated God" for people living in the industrialized world. ${ }^{6}$

SUMMER 2011 
In this essay, I undertake to show that this is indeed the case with both Levinas and Jonas, and to present a critical comparison of the different ways in which they go about this task. This procedure will shed light on the work of both. The comparative perspective that I develop here is guided by the following three-fold concern: first, to indicate how they interpret the crisis of the death of God; second, to comment on how they shift from that diagnosis to their justification of a unifying point of orientation for action, in other words, to compare their philosophies of responsibility; and third, to clarify the position of the context of the industrialised world-whence both philosophers argue-in their respective philosophies . After developing my perspective on these two philosophical projects, I conclude with a number of considerations that may be relevant to future projects comparing the work of Levinas and Jonas.

I would like to emphasize that I do not claim to present an exhaustive discussion of the topics indicated above, and even less a complete overview of the two philosophies in question-for this a proper monograph would be needed. However, I hope that my essay will contribute to the launching of such a larger project and to greater understanding of Jonas and Levinas, by means of a critical comparison.

\section{The "Death of God" or Nihilism, and the Opposing Orientation}

Although both Levinas and Jonas are deeply indebted to Heidegger, the task they undertook required them to distance themselves from Heidegger to some extent. The person that provides the "intellectual tools" to search for a solution also epitomizes the problem: Heidegger's philosophy might be that of a pagan (and calling it thus implies that his position is still criticized in theological terms), but much more significantly, in his work the individual is abandoned to fate. However, their effort cannot be reduced to their engagement in polemics with one person-it reflects their struggle with a broad cultural phenomenon in which ethics has collapsed or risks collapsing. Heidegger's work seems merely to give privileged access to this broader phenomenon.

\section{Disorientation}

For Jonas the fate that humans are abandoned to implies an ethical void. This nihilism may have an important precursor in ancient Gnosticism, but has reached its zenith in the twentieth century: "That nature does not care, one way or the other, is the true abyss. That only man cares, in his finitude facing nothing but death, alone with his contingency and the objective meaninglessness of his projecting meanings, is a truly unprecedented situation." () - thus Jonas summarizes the crisis of nihilism in his famous criticism of Heidegger (in "Gnosticism, Existentialism, and Nihilism." 9

Jonas identified three important aspects of nihilism. ${ }^{10}$ First, whereas in previous eras people's lives were oriented by their devout obedience to God, as the Creator of a world order that lends itself to people's orienting their existence to it, in an era of nihilism, people float around meaninglessly, as specks in the inhumanly large expanse of the universe. Thus they are subject to the relentless becoming of a universe that follows unconscious laws towards a future that has no demonstrable end or purpose. ${ }^{11}$ Second, even in their insignificant earthly existence, people's conduct is at the mercy of the urges of natural drives and the whims of superegos and other forces that spend themselves on human beings and that preclude divine direction. What remains of guiding values is a multitude of relative, context-determined or interest-informed notions, without ultimate reference. Deprived of a means to give order to this chaos, human beings ironically have to take the positions of both judging between these values and overseering their realization. Third, the calamity of this situation is exacerbated by modern technology, which strengthens human capacity to act on a hitherto undreamt of scale. The height of this newly acquired strength is the capability to intervene in the very processes by which the essence of human beings is determined and by which human beings are formed (notably in biotechnology).

\section{PHILOSOPHY TODAY}


This summary of nihilism, as Jonas sees it, should sound familiar to readers of Levinas. Being fatefully chained to history is the most prominent image that Levinas, since Quelques réflextions sur la philosophie de l'hitlérisme (1934) and De l'évasion (1935), uses to describe his problem in philosophy. ${ }^{12}$ If it is true that, as Heidegger argued, human existence is ontologically characterized by care (Sorge), this implies that every aspect of (human) existence has already been entrusted to or surrendered to the "brutal" flux of being that draws it along blindly. This means that "the essence of the human being is no longer in freedom, but in a kind of enslavement [enchaînement]" (IH 30).

It is only a small step from being subjected to this fate to accepting it. Levinas argues that "every civilization that accepts being, the tragic despair that it entails and the crimes that it justifies, deserves the name of barbaric" (EV 127). The first kind of "human fiasco" associated with the heroic assumption of the "act of being" (according to the terms of DVI 80) is to be found in the political catastrophes in which the particularity of vulnerable individuals is mercilessly subjugated to systems of totalitarian power. Ironically, by taking cognizance of the first kind of human fiasco, people are overwhelmed by the impotence of humanity to give an orientation to life. ${ }^{13}$

This in turn engenders the second kind of human fiasco: the loss of any affirmation of the possibility of orientation, in other words, succumbing to the despair of human life as a mere arbitrary element in the play of passions, and contingently constituted meaning. Philosophy and the humanities in general reflect this loss of orientation by their anti-Platonic structure, which entails a non-reducible plurality of cultural expressions and values, without ultimate orientation, which is often referred to as the "death of God" and what Levinas calls "the crisis of monotheism" (HH 40) and the plurality of contingent values. Any discourse that claims to represent or to have access to the ultimate and authoritative vocabulary or point of orientation, is - according to Levinas's reading of the main trend in contemporary reflection-nothing more than one amongst the multitude of historically constituted, culturally specific forms of meaning-giving or valuation that, furthermore, ignores its own finitude and situatedness. In the absence of any measure for judging cultural expressions, one floats inevitably in the sea of an indifferent plurality of expressions. ${ }^{14}$

\section{Orientation}

However, when one considers the two philosophers' responses to this crisis of disorientation, especially with regard to ethics, the difference between their positions is striking.

Jonas attempts to argue that the cosmos is not as indifferent as modern science would have it. The centre of his argument is a careful re-examination of the body (PL 19). This leads to an existential reading of the organism (PL ix) in which the Heideggerian notion of care is spread across all life: all life is suspended between birth and death, but this is a tension marked by care and the attempt to persevere in the living existence. Once this has been argued, it can be claimed (contrary to what nihilism, according to Jonas, entails) that nature does, in fact, care. And it is in the care of nature that the essence of ethicity is inscribed. Ontologically speaking, "in purposiveness as such ... we can see a fundamental self-affirmation of being, which posits it absolutely as the better over against nonbeing. . . . The mere fact that being is not indifferent toward itself makes its difference from nonbeing the basic value of all values, the first 'yes' in general" (PV 155/IR 81). ${ }^{15}$ Jonas believes that with this notion of the non-indifferent concern of nature for being, this natural teleology, he has acknowledged the enormous basis that is the "iceberg of our being, i.e., 'the broad organic basis on which the miracle of mind is perched"" (PE xii) by recognizing in it the conditions for a general intelligibility of care for life. Human beings, who are thus rehabilitated as the reflecting part of a caring organic life, would again be capable of engaging in ethical reflection and action. ${ }^{16}$

It would be difficult to conceive of a less Levinasian way to deal with the problem. For Levinas, at best, nature forms the décor in which humans act ethically or unethically toward one another. Very often, however, nature is the domain-phenomenologically described-of the

RESPONSIBILITY AND TECHNICS 
sacred as the numinous, the playground for and toys of capricious gods that terrorize defenseless human beings; it is the setting for the cruel struggle for survival (cf. TI 151). Nature, as it infiltrates the most intimate or hidden life of the individual, is that from which escape is needed; the conatus in suo esse perseverandi (Spinoza) is the human expression of being under the force of nature and living at the expense of others. One could argue that Levinas wants to posit precisely that we as humans are not only our nature (or to put it differently, although human beings are an identifiable form of biological existence), there is something "non-nature" in humans that is ultimately significant about human beings and that is decisive for our understanding of ethics. Typical of his argument is the duality of ageing (curiously enough, another attentive interpretation of the body): ${ }^{17}$ whilst ageing undeniably demonstrates the perseverance of an individual in his/ her being, it is at the same time, enigmatically, also a giving away of life. According to Levinas, it is a giving away that is directed at the other, submitted to the judgment of the advantage of the other (cf. AE 87-90). It is exactly the other in whose presence I live who makes it possible for me to transcend my own being, who gives my existence a more than ontological meaning, that is, an ethical meaning. It is by having one's entire existence directed as a response to the appeal emanating from the other that human existence is oriented, and that the value of whatever culturally specific forms of expression there are can be judged according to the fidelity with which they respond to the appeal of the other.

The consequence of these divergent responses to the problem of nihilism is an important contradiction that emerges from the work of Jonas and Levinas. Despite Jonas's strong effort to the contrary, for Levinas, Jonas's thought will remain in harmony with the deepest origin of nihilism, since it does not succeed in thinking of the meaning of human existence as beyond being or nature ${ }^{18}$ but, conversely, to Jonas, Levinas would appear nihilist, since the human subject, even face to face with the other, remains isolated from the organic basis in which it is implanted and from which its caring intervention in human affairs draws its intelligibility. ${ }^{19}$

In view of this conclusion, the agreement between the two authors on the ethical evidence regarding parenthood may strike us as surprising. For Jonas, parenthood provides the unmistakable archetype of the ethical imperative that is dictated by nature; for Levinas, parenthood, despite the natural propagation of the identity of the parent in the child, testifies to an unmistakable alterity (of the child with regard to the parent) that stamps the subject with an ethical obligation (cf. TA 85-87). However, since the position of their respective reflections on this subject needs to be carefully situated within the historical development of their work, for the moment I limit my observations to pointing out that they agree that the theoretical reduction of everything to is, to being, with the subsequent exclusion of ought, is not legitimate (PV 234-36). The finer qualifications of this "beyond is" are the focus of the next section.

\section{The Principle of Ethicity, The Principle of Responsibility}

Despite their widely divergent orientations, Jonas and Levinas concur in significant respects on the idea of ethicity, which they developed from these orientations. ${ }^{20}$

My comparison in this regard is complicated somewhat by the fact that I share the reading of a number of commentators on Jonas (not the least of which is Jonas himself, in his last essays) that consider his metaphysical project as having failed. ${ }^{21}$ However, I believe that a more flattering (although not completely unproblematic) reading of Jonas's work is possible, using his nonphilosophical, non-theological myth as a point of entry to his work on responsibility. ${ }^{22}$ Since I think that such a reading of Jonas opens up a number of additional avenues of exploration in comparing his work with that of Levinas, I first outline this reading. In comparing the work of Jonas and Levinas regarding issues related to the justification of responsibility, I clearly indicate when a point of comparison touches upon Jonas's normal, metaphysical foundation of ethics, or the

\section{PHILOSOPHY TODAY}


mythological justification in my unorthodox rereading thereof.

In essence, the Jonassian myth (PL 275ff.; PUV 193ff.) concerns a creator God who, after the creation, not only left the entire creation to itself, but with it left his (her?) own being to creation. It is through the long process of the formation of consciousness in life and later selfconsciousness in humanity that the divine comes to self-experience. ${ }^{23}$ This entails taking an enormous risk, since it means that in reality it is the creatures that henceforth decide the image of the Creator. This God never intervenes in history, but Jonas suggests that this God lets his/her shadow and light of disapproval and approval fall on human action.

Now, I have argued that this myth - a completely different genre of discourse from Jonas's metaphysics - in fact realizes the same intention as Jonas's metaphysical-ethical project (summarized above). This correspondence between Jonas's philosophical project and his myth can be schematized in the following manner:

\begin{tabular}{|l|l|l|}
\hline 1 & \multicolumn{1}{|c|}{ Philosophical Project } & \multicolumn{1}{|c|}{ Myth } \\
\hline 2 & $\begin{array}{l}\text { Construction of a philosophical } \\
\text { ethics after the "death of God" }\end{array}$ & $\begin{array}{l}\text { God recedes after creating the } \\
\text { world }\end{array}$ \\
\hline 3 & Sproader natural being & $\begin{array}{l}\text { Human beings develop out of a } \\
\text { process of evolution }\end{array}$ \\
\hline 4 & $\begin{array}{l}\text { Care is imbedded in the totality } \\
\text { of life }\end{array}$ & $\begin{array}{l}\text { God becomes self-conscious- } \\
\text { ness, ultimately, in the human } \\
\text { spirit }\end{array}$ \\
\hline 5 & $\begin{array}{l}\text { Affirmation of life is the begin- } \\
\text { ning of ethics, which culmi- } \\
\text { nates in human responsibility }\end{array}$ & $\begin{array}{l}\text { Human beings are capable of } \\
\text { affirming good against evil }\end{array}$ \\
\hline 6 & $\begin{array}{l}\text { Human beings respond to the } \\
\text { categorical imperative of care } \\
\text { for life }\end{array}$ & $\begin{array}{l}\text { Human beings take responsi- } \\
\text { bility for the image of God }\end{array}$ \\
\hline
\end{tabular}

This myth is not a forceful and binding argument; but unlike Jonas's metaphysics, it takes the philosophical tradition's criticism of metaphysics seriously - it takes human finitude seriously.
It is not an irreplaceable narrative; it serves to evoke an idea, after which the myth itself becomes redundant. As such, it works aesthetically: ${ }^{24}$ instead of providing us with a foundation of ethics, it describes the originary ethical mood of existence; the myth describes not humanity, but human being-in-the-world.

This myth, then, uses an image presented in narrative form to evoke the largest possible context of interpretation of all current facts and actions; it is only if such a context for the appearance of the problem is accepted that the world appears not merely as a given, but also as a problem. The first place in which the problematic nature of the world is noted is the subjective, emotional registration thereof, namely in the fear evoked by the possibility of the destruction of humanity. Human beings are more than agents of efficiency, because they are capable of a kind of fear in which they show themselves capable of recording the judgment of (the receding) God. ${ }^{25}$ It is here that the other as the ethically other takes possession of me in my capability to take responsibility for the other (PV 166). Furthermore, since this fear of the death of the other is not merely "pathological," but is indeed selfless and directed at the advantage of (other) people (PV $392),{ }^{26}$ it can activate the human agent to make the transition from being affected by the vulnerability of the other in fear to searching for an appropriate response by means of a heuristics of fear. ${ }^{27}$ Guided by the heuristics of fear, the ethical subject responds to the appeal of the other, in obedience to the categorical imperative of respect for the life of the other (PV 36).

A whole series of terms and ideas from this rendering of Jonas's philosophy of the principle of responsibility should strike readers of Levinas as familiar: the otherness ${ }^{28}$ of the other, which touches the subject as the mortality and vulnerability of the other (cf. AT 147; IH 179), imposes a relation of non-reciprocity or asymmetry (cf. PV 177f.; ${ }^{29}$ DEHH 174; EI 91) that is of ethical character. It is through this heteronomical imposition of an obligation that the subject's autonomy acquires its true significance (PV 170; DMT 226). Also, for both philosophers, responsibility characterizes the entire life of the subject as a re-

RESPONSIBILITY AND TECHNICS 
sponse to the appeal of the other and as a disinterested obedience (or disobedience) to the prohibition against the murder of the other (PV 186; TI 258; DMT 132), exercised in anxiety about the death of the other (DVI 256). This appeal (PV 162, 393, PUV 143; TI 238, EI 83), however, is not an empirical phenomenon, but, as Levinas presents it, refers to the enigma of the other that exists in the trace of an ever-receding God/illeity (DEHH 214). ${ }^{30}$ The "receptor" of the appeal is the ethical agent that contracts the obligation of responsibility passively (EI 89) and ironically remains inadequate to meet the responsibility which he/she is called on to take (PV 393).

Although there are remarkable similarities in the justifications of the philosophies of responsibility developed by Jonas and Levinas, the argument takes a different form in their writings: Jonas argues a collective ethics encompassing humanity as a whole, including generations to come and even nature; Levinas claims that every person has an obligation to his/her neighbor, expanding gradually to cover all living humans. ${ }^{31}$ Other important similarities (with their respective differences in nuance and approach) are explained in the subsections below.

Responsibility as ethicity: Although for Levinas, responsibility is conceived of from the perspective of the ethical response due to the other, and for Jonas responsibility is the name of ethics in the modern technical civilization (as is clear especially from his task description in PV Ch 1), for both, responsibility is the nature of the ethical as such (for Jonas, this is clear from his metaphysical foundation of ethics). ${ }^{32}$ The bulk of their philosophical energy is consecrated to the justification of the ethical as such and not to more practical indications of what is to be done or to be avoided. However, in Jonas's Technik, Medizin und Ethik, Jonas comes closer to the "praxis of the principle of responsibility" than Levinas does in his work.

Saying the unsayable: Provided that one accepts my "mythological" reading of Jonas, both authors could be seen as post-metaphysical thinkers. Their ethics is not based on an ontology (this argument would obviously not apply in the usual reading of Jonas); it is an ethics of human finitude. However, some form of exegesis (of the alterity of the other, in Levinas's case; of being affected by the other in fear, in Jonas's case) is reintroduced in order to save their philosophy from ethical muteness: Levinas speaks of testimony or prophecy - that event by which "I make myself the author of what I hear" (DVI 124). Jonas suggests that when we are affected by the other and know why we are affected in this way, this beingaffected is not merely "pathological". This means that both authors are obliged to commit what Levinas calls an "indiscretion with regards to the unsayable" (AE 19): the biggest part of Levinas's philosophy falls into this category, as does Jonas's myth when it is understood as an aesthetic evocation of the quality of human being-in-the-world (as argued above).

Claim to a non-contingent interpretation of the highest imperative: But this indiscretion is taken furthe, when Jonas is obliged to make a distinction between fear as a "pathological" response to the world and fear as the very first reading or recording of the meaning of the vulnerability of the other (PV 166). He, like all other ethical subjects, therefore has no other choice than to become the spokesperson for the God that has withdrawn completely from creation. The same holds for the Levinasian prophet in whose stead nobody can decide how to respond correctly to the appeal of the other. Both philosophers have thus claimed some capability for providing an exegesis of a supposed speech of a God that never appears. Both claim to be obliged to pronounce an ethical message that cannot (fully) have its origin and final expression in any cultural, historically contingent interpretation of responsibility.

Responsibility as reinterpretation of the zoon logon echon: For both philosophers, the inalienable imperative of responsibility decisively defines human being. Whereas Jonas merely claims that bearing responsibility belongs as much to being human as being gifted with speech (cf. PV 185), Levinas argues for the radically passive constitution of the subject of responsibility by the "language" of the appeal of the other, which stamps the subject with the quality of "saying" (dire), or as Levinas says, is a sign for the other (AE 83). For Jonas, it suffices to state that being

\section{PHILOSOPHY TODAY}


human is being responsible, but Levinas insists on the distinction or even separation of human responsibility from human animality (EN 161).

But for both Levinas and Jonas, responsibility is not only the name of ethicity as such, but also the name for the obligation that has to be realized in relation to other people. A number of further details of the relation between the authors need to be developed on this point.

Responsibility and love: In his earlier philosophy, Levinas shied away from the use of the word "love" for the ethical relation (since love exists, according to him, between two people only and thus the social aspect of ethics would be negated-cf. EN 30-31-or it retains a quality of seduction-AS 77), but he later approved of its use, provided that one understands love as "without concupiscence" and as referring to the transcendence of ethics (DMT 255-57). Philosophy even becomes the wisdom of love for him. For Jonas, love is responsibility practiced to the point of self-sacrifice (PV 175); however, he seems to be less interested in self-sacrifice to the point of saintliness than Levinas is.

Responsibility for the other's responsibility: The extent of the implications of the notion of responsibility is intensified when one considers that, for both authors, responsibility means deciding not only how to take care of the other, but also how to take care of the responsibility of the other (PV 89; EI 96). The other has to be taken care of also in the sense of helping or correcting the other in remaining responsible, but this would necessarily mean being responsible for the terms in which the ethical subject interprets the voice of "God". Whereas for Levinas the responsibility for the responsibility of the other implies primarily a movement or a constant call to greater vigilance to the task of responsibility, for Jonas, the emphasis is on the conditions of there being such a thing as a human being capable of bearing responsibility and being responsible (cf. PV 186), conditions that are under threat in the current technological system.

Conflated structure of responsibility: (1) Let it be assumed here that the very idea of responsibility implies (in its common use, at least) three aspects (the subject of responsibility, the domain of responsible action and the authority in the face of which one has to answer for one's actions). Micha Werner has argued compellingly that Jonas conflates the authority of responsibility and the domain of responsibility. ${ }^{33}$ This is clear in the matter of responsibility for future generations. The same conflation is found in Levinas's notion of responsibility: the other for whom the subject is responsible is always also the authority to whom the subject is obliged to answer for the ways the subject has adopted in responding to the appeal of the other. While the exact rationale for this conflation is not entirely clear to me, it certainly has the effect of supporting an understanding of responsibility as not dependent and limited by culture-specific institutions and ways of justifying action. (2) Furthermore, it should be noted that both Jonas and Levinas connect intimately causal responsibility with ethical responsibility. ${ }^{34}$ This is a result of identifying responsibility with ethicity as such and imbuing the entire human existence and scope of action with the quality of responsibility. The problem with this intimate connection is how to limit this responsibility once it has been affirmed. This is the problem of the transition from ethics to politics.

Responsibility, politics, justice: The two philosophers share the conviction that individually borne responsibility should lead to political action (Jonas's emphasis) or action aimed at a politics of improving justice (Levinas's emphasis). However, Jonas insists that for a responsible person who enters the domain of political action, prospective responsibility requires collective, that is, political action. This seems to impose itself on subjects, since the individual agent is helpless in the face of the magnitude of the problems posed by the technological era. By contrast, Levinas's political thinking is based on the hyper-individualist isolation of the ethical subject that nobody can replace, neither in his/her obligation for the others, nor in deciding what the realization of that obligation entails in practice. Any valid collective action remains a derivative of the individual realization of justice by individuals. Jonas and Levinas's perspectives probably do not preclude one another, but an articulation of the precise nature of their complementarity

RESPONSIBILITY AND TECHNICS 
(and the limits thereof) would have to be the subject of another study. ${ }^{35}$

\section{Technics and the Death of God}

One could present the thought of both Levinas and Jonas from the perspective of their fear of an unfolding of history in which ethics would come to an end, in which there would be no differentiation between good and bad, that is, the dawning of an era of indifference in which God would be dead. It is well known that Jonas saw this threat particularly in the historically unprecedented developments of contemporary technology. It is a complex threat, since it is not only the misuse of technology that could have disastrous consequences; apparently good applications of technology could have them too (WpE 28). By contrast, Levinas sees the threat of generalised indifference as lying in the divergent forms of tyranny-and believes that violence lurks even in states that function perfectly well ${ }^{36}$ - but he is also anxious about the ambiguous promise of technology, even if he only rarely notes this concern. Let us consider Jonas and Levinas in turn to clarify this matter and to show why this threat should be considered central in a study comparing their work.

If we reconsider the three elements responsible for contemporary nihilism that Jonas identifies, it is clear that the third-modern technology - is the one that is most important to him. Or to be more precise, it is this that occupies the largest part of his later work, whereas his response to the first element of nihilism-the absence of God-is presented in The Phenomenon of Life and concluded in Das Prinzip Verantwortung. (Jonas neglects the second element of nihilism somewhat. ${ }^{37}$ One could argue that in his approach to nihilism, he is implicitly convinced that once the other two elements have been resolved, human reason would be able to give some guidelines that could give some form of order to the chaos of human values. Such a reason would be able to give guidelines - or even draw up a casuistics-around which tolerably different cultural specific values could be rearranged.) These two issues are intimately linked: a certain vision of nature and a certain vision of instru- mentality imply one another. What does this mutual implication entail?

Without entering into the details of Jonas's theory of modern technology (see especially PV ch. 1), it is essential to understand the position of a reflection about technology in Jonas's work, which is deeply concerned with the vulnerability, not only of nature, but also, and especially, of humanity. The issue of technology is not incidental to this author; it is not merely one domain among many in which he applies pre-established ethical principles. Modern technology follows in the wake of the crisis of (Western) dualism, a crisis that has been in existence for two thousand years, in which human beings have become detached from the value-structure inscribed in the very fiber of nature. From this perspective, modern technology coincides historically with the death of God and shares the same origin. Furthermore, modern technology has changed the givens of the human condition in such a manner as to render all previous ethics obsolete, at least with regard to some of the most pressing contemporary questions, as many of these problems are themselves a result of the development of technology in the modern era (cf. PV 31, 57). ${ }^{38}$

For Levinas, technics is also associated with a certain "death of God," but in a completely different way. The part of human existence that we call technical capability is what first made it possible to start freeing human beings from the hold that nature had on them. As such, the emergence of technics in the life of humans as a biological species is intimately linked to the capability to relativize the effect of human beings' merciless exposure to the elements, which was for a long time experienced and expressed as the reign of the capricious gods. Technics could be considered a human capability that is inherently secularising, since, in this sense, technics infringes on the domain of the gods. Therefore the emergence of technics could be considered to announce the death of religious gods. And this is not only a phenomenon of modernity-its roots are to be found in antiquity. ${ }^{39}$

However, this argument does not hold for the God of the "monotheism" that Levinas wants to rehabilitate in philosophy (which is not simply

\section{PHILOSOPHY TODAY}


the monotheism of Judaism). This God is completely out of reach of technology; in fact, technics should be considered (as I stated in the introduction) an extension of the human I can; the God of Levinas's philosophical "monotheism" is, however, not contaminated by being (AE $\mathrm{X}) .{ }^{40}$ If this is then the status that Levinas accords God and technics, it means that the entire domain of human technicity falls in the category of the existence of the subject, that is, the domain of possibilities of reacting to the appeal of the other. If this argument is accepted, one has to conclude that, for Levinas, technics in itself is ethically indifferent-its ethical importance lies in its being a force that liberates human beings from the order of nature and allows them to act as ethical agents, ${ }^{41}$ but otherwise technics has ethical significance only in so far as it is embedded in one or another project of response to the other.

In the few texts that Levinas devoted to technics, this does indeed appear to be the case. ${ }^{42}$ The technical development of humanity, particularly since the dawn of modernity, is inscribed in a double dialectics. First, the same technology that makes it possible, now more than ever before, to feed the hungry is also responsible for the destruction of the environment in which people are to live. Second, the same technics that makes the modern state with its human rights and their implementation possible could make it possible to trample on those rights and oppress the citizens. Ultimately, everything depends on the way in which technics is incorporated into the exercise of realizing justice in the face of the appeal of the other. In this sense, the appeal of the other, in combination with the ethical subject's responses to it, determines how technics should be evaluated.

\section{Conclusion}

If Heidegger was convinced that rigorous philosophical thought is serious reflection about being, Jonas and Levinas decentered this ontological concern in favor of an ethical concern. "Decentering" ontology does not mean invalidating reflection on it, but rather continuing to pursue thought about being in the service of another concern, in this case, concern about the ethical.
Both these authors' redirection of Leibniz's question, "Why is there anything at all rather than nothing?" is telling in this regard.

For Jonas this question remains nonsensical and inevitably falls into an infinite regress as long as the "why?" is to be answered by a "causal whence?" (cf. PV 99). However, the question retains its importance when the "why?" is answered by a normative justification. "Why is there something?" should be answered by a justification of the value of the existence of this something. Hence the question should be reformulated: whatever the causal grounds for the existence of things may be, why ought existence to have priority over nothingness? (cf. PV 99). It is the question concerning this ought that takes centre stage in philosophy and (as far as Jonas's metaphysics is concerned) will lead to the claim that this normative justification should be situated in the phenomenon of life, since "every living being is its own end, without any need for further justification" (PV 184). Obeying the imperative implied in such a justified end is the essence of Jonas's ethics. ${ }^{43}$

Levinas remains convinced that the entire human being is ontology (cf. EN 13), even while he exerts himself to show that the meaning of being human should not be reduced to the ontological. The decisive question is this: What is the place that I take in being? And at whose expense do I hold that place (cf. AT 180)? And this is, according to Levinas, the first question concerning the meaning of being — not the ontological question about being ("Why is there something rather than nothing?"), but the question of the justice or ethics of being ("Do I have the right to be?" or "Is my existence justified?") (cf. DVI 257). Haunted by this question, one would then live in such a manner as to sacrifice or suspend, as it were, one's own existence and to live "as if one is not a being amongst the beings" (cf. EI 97).

This article has attempted to explore a number of points in which the efforts of Jonas and Levinas to ethically decenter the question concerning being overlap-whether they concur or differ on these points. I am confident that this article makes a contribution to the existing research on Levinas and Jonas, yet, it remains only a step

RESPONSIBILITY AND TECHNICS 
towards an urgently needed in-depth study on Jonas and Levinas - not only for the sake of the clarification that it would give concerning their respective projects, but especially for the understanding that it could bring in respect of their philosophical concerns. In conclusion, I would like to enumerate a few points that my work in the current article suggests regarding the requirements for such a larger comparison between Levinas and Jonas. The following seems to me to be indispensable for such a project:

1. Consideration should be given to the theories of secularization and modernity proposed by Levinas and Jonas and these theories should be submitted to critical scrutiny. The nature of the technological system would obviously take an important position in such a study. Not only should the current state of globalization be taken into account, but the current state of social and institutional technologies should be given due consideration. These social and institutional technologies are especially important for a realistic assessment of the current situation and the capability of people to bear responsibility. Also, the current state of secularization should be questioned in relation to the two philosophies.

2. A number of issues relating to the core issue of responsibility in Levinas and Jonas need to be examined. First, the relation between responsibility as the very nature of the ethical, or of ethicity, and the practice of responsibility as a form of ethics should be clarified. Second, the structure of responsibility needs clarificationthis is especially true for the question of collective responsibility. Third, the relation between responsibility and other forms of ethics, and other discourses on praxis, in particular politics and

1. Reading Jonas and Levinas, one is struck, not only by the obvious similarities and interesting convergences between the two authors, but also by the relative scarcity of studies that compare them and the fact that these studies remain on an exploratory level. In this essay, I attempt to expand the possibilities of such a comparison. Given the limited scope of an article of this nature, I am forced to refer to my own studies on Jonas and Levinas frequently — not as an exercise of technology, have to be unraveled. Fourth, the relation between humanity and nature as beneficiaries of responsibility has to be considered. In my opinion, all of this should be done in such a way as to respect the immediate, local ethical engagement of individuals, but at the same time the global condition of contemporary human existence should remain the ultimate horizon of such reflection.

3. The articulation between all of the previous points and the continued (benevolent and harmful) existence of religion and theology should be examined. Not only should Jonas's and Levinas's own views on this articulation be considered, but also the way in which this issue is contextualized in current debates on the issue.

4. The appropriate philosophical discourse(s) to be adopted in reflecting on ethics and on the ethics of responsibility in particular should be reflected on. Such a reflection, which would take the contributions of Jonas and Levinas as its point of departure, would require a detailed comparison between their philosophical discourses and that of Heidegger. This reflection would ultimately involve investigating the question of the relation between conflicting claims about what the appropriate manner is to think the ethical in continental philosophy and beyond. One could, for instance, consider the tension between such divergent thinkers as Karl-Otto Apel (who, in his later work on responsibility, explicitly seeks to extend some of Jonas's concerns by means of his version of discourse ethics $)^{44}$ and Jean-François Lyotard (in whose central work on ethics essential aspects of Levinas's thought are taken over and adjusted to Lyotard's own project). ${ }^{45}$

conceited narcissism, but to support numerous points of analysis of the respective philosophers and secondary literature on them that cannot be repeated here. An account is given of the existing work comparing Jonas and Levinas in the footnotes, with the explicit objective of providing the reader with an overview of the existing literature in this field of enquiry. I would like to argue that the current article either corrects or supplements these existing studies.

\section{PHILOSOPHY TODAY}


The following abbreviations are used for in-text citations: For Jonas: PL: The Phenomenon of Life: Toward a Philosophical Biology (Chicago/London: University of Chicago Press, 1966); PE: Philosophical Essays: From Ancient Creed to Technological Man (Englewood Cliffs, New Jersey: Prentice-Hall, 1974); PV: Das Prinzip Verantwortung: Versuch einer Ethik für die technologische Zivilisation (Frankfurt-am-Main: Suhrkamp, [1979]1984); WpE: Wissenschaft als persönliches Erlebnis (Göttingen: Vandenhoeck \& Ruprecht, 1987); and PUV: Philosophische Untersuchungen und metaphysische Vermutungen (Frankfurt-am-Main/ Leibzig: Insel Verlag, 1992). The books are referred to in the language in which they first appeared. For Das Prinzip Verantwortung, I used the translation entitled The Imperative of Responsibility: In Search of an Ethics for the Technological Age (Chicago/ London: University of Chicago Press, 1984)—abbreviated as IR. The page numbers refer first to the page in the German text and then to the page in the English translation; for references without quotations, the page numbers refer to the German text, where that is the original and first publication. For Levinas: EV: De l'évasion (Montpellier: Fata Morgana, [1935]1982); TA: Le temps et l'autre (Paris: PUF, [1947]1998); DEHH: En découvrant l'existence avec Husserl et Heidegger (Paris: Vrin [1967]1998); TI: Totalité et infini: Essai sur l'extériorité (Paris: Kluwer Academic, [1961] 1998); HH: Humanisme de l'autre homme (Montpellier: Fata Morgana, 1972); DL: Difficile Liberté: Essais sur le judaisme (Paris: Albin Michel, 1976); AE: Autrement qu'être ou au-delà de l'essence (Dortrecht: Martinus Nijhoff, [1974] 1986); EI: Éthique et infini (Paris: Fayard, 1982); DVI: De Dieu qui vient à l'idée (Paris: Vrin, [1982] 1992); AS: Autrement que savoir (Paris: Editions Osiris, 1988); HN: A l'heure des nations (Paris: Minuit, 1988); EN: Entre nous: Essais sur le penserà-l'autre (Paris: Grasset, 1991); DMT: Dieu, la mort et le temps (Paris: Grasset, 1993); IH: Les imprévus de l'histoire (Montpellier: Fata Morgana, 1994); LC: Liberté et commandement (Montpellier: Fata Morgana, 1994); AT: Altérité et transcendance (Montpellier: Fata Morgana, 1995).

2. Lawrence Vogel, "Jewish Philosophies after Heidegger: Levinas and Jonas on responsibility," in W. Davis, ed., Taking Responsibility: Comparative Perspectives (Charlottesville: University Press of Virginia, 2001), 121-48, hugely exaggerates, not so much the Jewishness of the two philosophers, nor the fact that their philosophy bears traces of their personal religious convictions, but the Judaic - in other words, the theological, confessional-quality of their philosophy. According to him, Jonas and Levinas both have a "distinctively Judaic philosophy", by which he means "a philosophy that articulates one's Jewish faith and so includes theological reflection and affirmation" (122). He goes so far as to suggest that Jonas and Levinas would dispute elements of each other's philosophy on the basis of their fidelity to articles of Jewish faith (141). The result is, in my opinion, a markedly distorted presentation of both philosophers. The essence of this presentation can be summarized by saying that, according to Vogel, what they argue for by the exclusive means of philosophical discourse is just a bonus by which nonJews can be brought "into the orbit of Judaic experience" (139-40). One example will suffice to illustrate my point: Vogel claims that "Levinas's phenomenological turn brings all humans into the orbit of Judaic experience because the I/You encounter, constitutive of being a human agent, bears pre-philosophical and even pre-textual testimony to the Judaic understanding of the relationship between humanity and God" (139-40) - indeed, it is so important to Vogel to identify Levinas as a Jewish philosopher that he turns Levinas's philosophy upside-down: the face of the other becomes a testimony to Judaism, instead of Judaism's being one amongst many possible testimonies of an ethical appeal coming from the other. It would be prudent to consider The Phenomenon of Life, where Jonas qualifies the expression "the secular philosopher" as "a redundant expression" (245); likewise, I think Levinas should be taken seriously when he explains: "I always make a clear distinction in what I write between the confessional and the philosophical texts. I don't deny that there could in fact be a source of common inspiration. I only claim that it is necessary to draw a line of demarcation between the two as having distinct methods of exegesis and separate languages" (my translation). "De la phénoménologie à l'éthique" (Interview with Richard Kearney), Esprit 234 (1997): 121-40.

A much more sophisticated approach is to be found in Walter Lesch's "Ethische Argumentation im jüdischen Kontext: Zum Verständnis von Ethik bei Emmanuel Levinas und Hans Jonas," Freiburger Zeitschrift für Philosophie und Theologie 38/ 3 (1991): 443-69. He explains his approach as follows: "Es kann nicht darum gehen, ihrer

RESPONSIBILITY AND TECHNICS 
unmißverständlichen philosophischen Identität um jeden Preis eine religiöse Dimension entlocken zu wollen. Ich möchte lediglich der Frage nachgehen, inwieweit der Kontext jüdischer Erfahrung, der mehr umfaßt als eine religiöse Sozialisation, den Text des ethischen Argumentierens beim Entdecken und Begründen von Werten beeinflußt"(445). Hence, he suggests a non-confessional-religious frame of interpretation (cf. 445). In this way he arrives at a perspective on Jonas and Levinas that differs considerably from Vogel's: "Wir sind von der Frage nach dem jüdischen Kontext ausgegangen und haben gesehen, daß dieser in Jonas' Ethik völlig verschwindet und durch eine metaphysische Ethik ersetzt wird. Aber auch Levinas versteht sich primär als Philosoph, kritisiert allerdings den herrschenden Diskurs der abendländischen Philosophie, die er durch eine neuartige ethische Sprache überwindet" (467). I attempted to give an account of the complicated relation between both these philosophers and their identifiable theological texts in "Responsibility in an Era of Modern Technology and Nihilism, Part 1. A NonFoundational Rereading of Jonas," Dialogue 48 (2009): 577-99, and in "Giving Up Your Place in History: The 'Position' of Levinas in Philosophy and Jewish Thought," Journal for Semitics 16 (2007): 180-93.

3. Jonas declared: "Although I cannot and may not forget what is between us-it remains that you [Heidegger] have been my decisive teacher and that you have never ceased to be a source of philosophical inspiration for me" (translated from the citation of Jacques Taminiaux in "Les enjeux d'une lecture gnostique de Sein und Zeit," in Sillages phénoménologiques: Auditeurs et lecteurs de Heidegger [Bruxelles/Paris: Ousia, 2002], 134). For Levinas, Sein und Zeit is one of the most beautiful books in the history of Western philosophy (Éthique et infini, 27) and he describes his own work as springing from an "incessant attention to Sein und Zeit" (Totalité et infini, I).

4. Cf. Martin Heidegger, Sein und Zeit (Tübingen: Max Niemeyer Verlag, [1927]1993), especially $\$ 63$.

5. For an exposition of Heidegger's "pragmatism", cf. Carl Friedrich Gethmann, "Heideggers Konzeption des Handelns in Sein und Zeit," in Heidegger und die praktische Philosophie, ed. Annemarie GethmannSiefert and Otto Pöggeler (Frankfurt-am-Main: Suhrkamp, 1988), 140-76.

\section{PHILOSOPHY TODAY}

6. Héctor Mandrioni has adopted a different strategy of comparison between Jonas, Levinas and Heidegger. "Responsabilidad y temporalidad," Escritos de Filosofia 14 (1995): 43-67. Instead of using Jonas and Levinas's indebtedness to Heidegger as his point of departure, he juxtaposes the philosophies of all three in order to gain clarity on the semantic tension between a "logic of free initiative" and a "logic of obedience" in the notion of "responsibility". He thus arrives at a complex five-fold comparison of the three authors, covering, first, the passivity of the subject in the imposition of responsibility; second, a comparison of the relation between being and responsibility in all three philosophers; third, the similarity of responsibility as constituted by an appeal; fourth, an indication of the relation between the individual's freedom and the locus of initiative in action; and, fifth, a schematization of the temporality of responsibility in which Levinas's accent is on the immemorial past, Heidegger's is argued to be on the present, and Jonas's is directed at the future.

7. Both Jonas and Levinas identify nihilism or the death of God with Heidegger's philosophy (The Phenomenon of Life, ch. 9; Humanisme de l'autre homme, ch. 1). For Heidegger's "paganism," cf. PL 249 (Jonas) and En découvrant l'existence, 171 (Levinas). On the link between Heidegger's philosophy and fate, cf. The Phenomenon of Life, 245, and the entire De l'évasion (implicitly) and De Dieu qui vient à l'idée, 147.

8. PL 233.

9. Ibid., ch. 9.

10. For what follows, see "Contemporary problems in ethics from a Jewish perspective" (Philosophical Essays, ch. 8).

11. One can find important points of convergence between Jonas's sketch of secularisation and Levinas's notion of secularisation (as discussed briefly below).

12. For a detailed commentary on the unfolding of Levinas's philosophical problem in these two essays, see Chapter 5, §1, of my Political Responsibility for a Globalised World: After Levinas' Humanism (Bielefeld: Transcript, 2011).

13. De Dieu qui vient à l'idée, 85 . For these two forms of fiasco, see "De la déficience sans souci au sens nouveau" (ibid., 77-89) and my commentary on it in De l'éthique à la justice: Langage et politique dans la philosophie de Lévinas (Phaenomenologica 183) (Dordrecht: Springer, 2007), 351-55. 
14. For an extended discussion of this problem, see Chapter 5 of my Political Responsibility for a Globalised World. If one were to write a comparison of Jonas and Levinas's ideas of the God of religion, one would have to note that the death or, at least, the withdrawal of God plays a very important role for them. Negatively, Auschwitz (and what it stands for) marks a rupture with preceding forms of theology (Jonas: "für den Juden . . . ist Gott eminent der Herr der Geschichte, und da stellt 'Auschwitz' selbst für den Gläubigen den ganzen überlieferten Gottesbegriff in Frage" (Philosophische Untersuchungen, 193); Levinas: "Ce Dieu a encore une voix. Il parle avec une voix muette, et cette parole est écoutée. Mais ce Dieu est le Dieu mort de Nietzsche. Il s'est suicidé à Auschwitz." "Visage et violence première," interview in La différence comme non-indifférence: Ethique et altérité chez Emmanuel Lévinas (Paris: Kimé, 1995), 129-43. This is attested to in the theological aspect or implications of Jonas's essay on "Der Gottesbegriff nach Auschwitz" (Philosophische Untersuchungen, 190-208, which cannot be viewed as a purely theological text) and, for instance, in Levinas's "Judaïsme et kénose" (A l'heure des nations, 133-51). In the latter, Levinas believes there is wisdom to be found "after the Shoah" (140), by arguing that one of the primordial meanings of "kenosis" can be found in the following idea: "Plus importante que la toute-puissance de Dieu est la subordination de cette puissance au consentment éthique de l'homme" (145), by which is meant, "Dieu a subordonné son efficacité . . . à mon mérite et démérite; mais ainsi précisément Dieu ne règne que par l'entremise d'un ordre éthique, là où un être répond d'un autre" (145). The God referred to here also suffers in the suffering of people (149). In Richard Bernstein's comparison of Jonas and Levinas's philosophy on the theme of evil, Auschwitz is correctly indicated as "evil exemplified" and thus as a concrete manifestation of the problem of nihilism. See Radical Evil: A Philosophical Interrogation (Cambridge: Polity, 2002), 185. After two separate chapters on Levinas and Jonas, a short comparison is given on pp. 201-204. It is from this problem that the question concerning responsibility develops for both authors. I shall come back to the detail of Bernstein's comparison.

15. "In der Zielstrebigkeit als solcher ... können wir eine grundsätzliche Selbstbejahung des Seins sehen, die es absolut als das Bessere gegenüber dem Nichtsein setzt. ... die bloße Tatsache, daß das Sein nicht indifferent gegen sich selbst ist, macht seine Differenz vom Nichtsein zum Grundwert aller Werte, zum ersten Ja überhaupt" (Das Prinzip Verantwortung, $155)$.

16. For the way in which Jonas opposes Heidegger by means of this philosophy of nature, see Jacques Taminiaux, The Metamorphoses of Phenomenological Reduction (Milwaukee: Marquette University Press, 2004), 49-50.

17. Again see ibid., 50-56, for Levinas's opposition to the "implied disembodiment" (49) of Heidegger's notion of authentic care. (However, Taminiaux bases his remarks on Levinas's early phenomenology of the body, whereas the phenomenology of ageing comes from his later philosophy.) Taminiaux's text does not do much more than to juxtapose Jonas and Levinas, but deserves mention, because it contains a rare attempt to establish a connection between the methodologies of the two philosophers.

18. In fact, in Jonas's insistence on the self-affirmation of life, i.e., "Daß es dem Sein um etwas geht" (Das Prinzip Verantwortung, 156), Levinas would hear an echo of the Heideggerian conviction that "das Sein ist es, darum es diesem Seienden je selbst geht" (Heidegger, Sein und Zeit, 42), which lies at the heart of Levinas's objection to Heidegger's ontology. Cf. Levinas's "Post-scriptum," in Quelques réflexions sur la philosophie de l'hitlérisme (Paris: Rivages, 1997), 25.

19. In a rare attempt to lessen the opposition between the two authors on the relation between ontology and ethics, Bernstein suggests that "in Levinasian terminology, we can say that Jonas shows that there is a way of understanding ontology and the living body that does justice to the nonreducible alterity of the other [as Levinas does-EW]" (Radical Evil, 191). However, he does not develop this idea, and it is not clear how this could be done, especially since he also recognizes that it "is disingenuous to try to smooth out their differences and underestimate their conflicting - and at times contradictory-claims" (201). Consequently, he develops this contrast between the two authors and here one has to agree with him. Looking from the side of Jonas's perspective, Bernstein argues that "Jonas would never accept Levinas's deep skepticism regarding the philosophical enterprise of ontology" (201-02). An evolutionary approach to ontology such as Jonas's allows both continuity and difference to be taken into account,

RESPONSIBILITY AND TECHNICS 
rather than simply abandoning ontology en gros to the criticism of totality (202). Jonas may have detected "the vestiges of a type of dualistic thinking" (202) in Levinas's ideas concerning the way in which ethics breaks with being. Contrary to Jonas, Levinas never awards anything more than a marginal position to the protection of nature (202). Also, Levinas does not reflect on the issue of the manner in which modern technology has changed the nature of human action. However, from a Levinasian perspective, Bernstein estimates that Jonas, unlike Levinas, "comes close to neglecting the particularity and concreteness of the ethical relation", in particular with our contemporaries (202-03). This remark does, however, seem to lose some of its validity when one notes the distinction in Jonas's philosophy between responsibility as ethicity, and responsibility as a foundational rule-responsibility as a foundational rule is an appropriate additional ethics for our era of advanced technology, but cannot claim to be appropriate in addressing all ethical problems (for more detail on this duality of Jonas's ethics of responsibility, see my "Responsibility in an Era of Modern Techology and Nihilism, Part 2: Inter-connection and Implications of the Two Notions of Responsibility in Jonas," Dialogue 48 (2009), 841-66, especially $\S 4$.

20. In Evaldo Kuiava's article "A responsabilidade como princípio ético em H. Jonas e E. Levinas: uma aproximação," Veritas 51 (June 2006): 55-60, the commentator takes as a point of orientation the fact that for Jonas and Levinas, responsibility is not only the central notion of their ethics, but also the beginning of ethics itself or the "principle of ethics" (56). According to Kuiava, philosophy traditionally presented free choice as the condition for responsibility and considered responsibility as something derived from liberty, but he argues that freedom needs responsibility as a challenge through which to affirm itself. Liberty affirms itself through the choice of moral principles by which it directs itself in specific contexts. The validity of the principles adopted in this way is in turn subject to social dispute. Hence, the need for those in public office to answer for their decisions with recourse to the common good. It is at this point that the work of Levinas and Jonas becomes relevant. Jonas's notion of responsibility for the continued existence of humanity, expressed in his reformulation of the categorical imperative, demands a change in perspective for those in positions of power: power should be exercised "for the other," rather than "over the other" (58). This is not a responsibility exercised individually, but by the holders of responsibility in consultation with technical and legal experts for the well-being of everybody, and in particular in projects of social justice. From this perspective, responsibility is the condition for the possibility of returning to a just freedom; it is social justice that justifies freedom (58). Defending this perspective is, according to Kuiava's interpretation, equally the task that Levinas set himself. For Levinas, the subject, rationality and all, is so much structured by this ethical condition, and responsible to such an extent, that he/she has to live as if he/she does not belong to the domain of being, which means, in Socrates's terms, that it is better to suffer injustice than to commit it. For Kuiava, in the political domain, this implies that the holders of power act under the control of the citizens and in service of their control (59). Whereas I find the argument about justice in Levinas unconvincing, I agree with Kuiava's insistence on the original position of responsibility that finally calls for justice.

21. See especially Philosophische Untersuchungen, ch. 6. Hans Achterhuis pointed out this doubt expressed by Jonas with regard to his earlier undertaking in "Hans Jonas: ethiek en techniek," in De maat van de techniek, ed. H. Achterhuis (Baarn: Ambo, 1992), 164-65.

22. This argument has been developed in detail in my article, "Responsibility in an Era of Modern Technology and Nihilism, Part 1: A Non-Foundational Rereading of Jonas," 577-99.

23. ". . . kommt die Gottheit zur Erfahrung ihrer selbst" (Philosophische Untersuchungen, 195).

24. This aesthetic working of Jonas's myth has been analyzed very convincingly by Albrecht Wellmer, "Der Mythos vom leidenden und werdenden Gott: Fragen an Hans Jonas," in Endspiele: Die unversöhnliche Moderne (Frankfurt am Main: Suhrkamp, 1993), 250-256, especially 252 .

25. "Daß Menschen potentiell schon 'moralische Wesen' sind, weil sie diese Affizierbarkeit besitzen, und nur dadurch auch moralisch sein können" (Das Prinzip Verantwortung, 164). It is by this affectability that agents of responsibility "capture" God's "shadow and light of disapproval and approval" of which there is question in Jonas's myth. Note that the attestation of human morality by the capacity of being affectable is also part of Jonas's myth and of his metaphysics proper.

\section{PHILOSOPHY TODAY}


26. Cf. also Jonas's intervention in "Vom Profit zur Ethik und zurück: Technik-Verantwortung im Unternehmen" (Hans Jonas in conversation with Walther Zimmerli et al.), in Ethik für die Zukunft: Im Diskurs mit Hans Jonas, ed. D. Böhler and I. Hoppe (München: C. H. Beck, 1994), 241.

27. That there are in fact two kinds of fear at work in Jonas's texts, is not immediately clear-I have argued for it in $\S 3$ of "Responsibility in an era of modern technology and nihilism, Part 2."

30. "Gerade die Andersheit nimmt von meiner Verantwortung Besitz, und keine Aneignung ist hier intendiert" (Das Prinzip Verantwortung, 166).

29. However, not all ethical relations in Jonas are characterized by asymmetry: asymmetry is typical of prospective responsibility. Given this qualification, one could contradict Bernstein's observation that the fundamental Levinasian theme of "an asymmetrical, nonreciprocal relation to the other ... [is] foreign to Jonas's philosophical thinking" (Radical Evil,184).

30. If Levinas's "God" is otherwise than being (cf. Autrement qu'être, $\mathrm{x}$ ), Jonas's God-at least according to his myth - has abandoned his/her being to creation. However, although an independent existence is denied for God in both cases, God still has an enigmatic manner of "speaking": by being in the trace of the other (Levinas) or by letting light and shadow of judgment fall on people (Jonas). The theological inspiration of these ideas of a commanding but fragile God (in Jonas, but with some remarks comparing Jonas's views with those of Levinas) has been commented on by Caterina Rea in "Retrait de Dieu et question du mal: Une lecture éthique du mythe de Hans Jonas," Revue philosophique de Louvain 100 (2002):, 535-45. Let it be mentioned here that the "methodology" of imagination adopted by Jonas in creating his myth is not completely absent from Levinas's work. His "phenomenological" descriptions of the "there is" (il $y$ a) depend on a fictive phenomenological reduction (fictive, since, by means of this procedure, the very phenomenologist is also placed in parenthesis). In both cases, the fiction serves to suggest a narrative glimpse on the largest horizon or primal mood in which the diagnosis of historical developments and the ethical response to it can be argued to make sense. For Jonas, see my essay "Responsibility in an Era of Modern Technology and Nihilism, Part 1," 589-90; for Levinas and the "reduction by imagination", see my De l'éthique à la justice, 49-52.
31. On the different understandings of the scope and perspective of responsibility in Jonas and Levinas, see Walter Lesch, "Ethische Argumentation im jüdischen Kontext: Zum Verständnis von Ethik bei Emmanuel Levinas und Hans Jonas," 460-62.

32. It is possible to demonstrate that in fact there is not one philosophy of responsibility, but two different philosophies of responsibility in Jonas-one is ethicity as such and the other is a more particular ethics for a specific era of human history, as I have tried to do in $\S 4$ of "Responsibility in an Era of Modern Technology and Nihilism, Part 2."An attempt to contrast Jonas's ontologically founded ethics with Levinas's, which draws on the "otherwise than being," was made by Wendy Hablet in "To Being or Not To Being? That is the Question of Ethics," Analecta Husserliana 84 (2005): 357-64. Unfortunately, because this essay is an unsophisticated simplification of these two philosophies and the relation between them, it does not make a convincing contribution to the field of enquiry.

33. Micha Werner, "Dimensionen der Verantwortung: Ein Werkstattbericht zur Zukunftsethik von Hans Jonas," in Ethik für die Zukunft: Im Diskurs mit Hans Jonas, 311.

34. This is not the place to go into the complexity of this problem. It has been discussed by Paul Ricoeur in "Le concept de responsabilité: Essai d'analyse sémantique," in Le juste 1 (Paris: Edition Esprit, 1995), 41-70.

35. A number of contributions to this question have already been made. Zygmunt Bauman, "Morality Begins at Home: Or the Rocky Road to Justice," in Postmodernity and its Discontents (New York: New York University Press, 1997), 46-70, recognizes that Levinas does not pay much attention to the processes by which individual ethical responsibility has to find its generalized realization in the State and its institutions (52). This is regrettable, according to Bauman, since these institutions sometimes have to act counter to the demands of ethics. According to Bauman, Jonas, with his historical perspective, is much more useful and complements Levinas in this domain. Central to the merit of Jonas in this regard is the guiding help that the heuristics of fear and the primacy of the prophecy of doom over the prophecy of success give in a context of normative uncertainty. Bauman's criticism of Jonas is unfortunately based on a rationalist reduction of the heuristics of fear (leading him to conclude, for instance, that there would be no

RESPONSIBILITY AND TECHNICS 
room in this heuristic process for the unanticipated consequences of human action, for actions left out of the heuristic process or that would have been left out of consideration at the time of action; Bauman also ignores Jonas's political realism (cf. 55 with Das Prinzip Verantwortung, chp 2, §8). Bauman argues that the current state of the world is due to "the increasingly deregulated market forces, exempt from all effective political control and guided solely by the pressures of competitiveness" (56), which makes ethical demands inaudible - and this agrees with the spirit of Jonas's diagnostic of the technological era. Bauman considers Jonas's heuristics of fear to be insufficiently demanding for "the macro-ethical extension of moral responsibility for the Other" (but seems not to give adequate attention to the full depth of Jonas's argument for responsibility as ethicity). Baumann then turns back to Levinas, who recognises the "demandingness" of the macro-ethical context that would be situated in the quest for ever-improving justice (and not merely in defending humanity against shared dangers, as Jonas apparently argues). The moral sensitivity needed to respond to this macro-demand is acquired in the microcontext of the relation to the nearby other (69-70).

In "Thinking Educational Ethics with Levinas and Jonas," in Levinas and Education: At the Intersection of Faith and Reason, ed. D. Egéa-Kuehne (New York: Routledge, 2008), 150-69, Eirick Prairat prepared an outline of an ethics for educators by examining the notion of responsibility in Levinas and Jonas, and in particular the manner in which this notion applies to the educational situation. This issue, which is intimately associated with the existence of the modern State and the integration of its citizens into the State by means of major institutions, seems to me to be of central importance for the question of ethics, politics, and justice. Prairat advocates that educators should take up their responsibility, which he understands as solicitude, and as based on an asymmetrical relation, following Levinas, that proceeds from the face of the other and that obliges the subject to responsibility. This is a responsibility not for the self, but for the other, before any action that is to be answered for. Despite his different starting point, Jonas's philosophy of responsibility "resonates" (161) with that of Levinas. Based on the urgency to rethink ethical agency in the era of modern technology, Prairat stresses the disinterested fear of Jonas's heuristics of fear as a means of access to what is fragile and what is at stake and the realization of this fra- gility reveals the imperative for humanity to be: "Jonas introduces the concern about consequences and distant future; he precisely sets the ignorance about the ultimate effects of our actions as the very reason for responsible restraint. Beyond this dimension of consequence, it is the theme of the "heuristics of fear' we would like to retain because it helps us understand how the call of the Other can truly mobilize me and in which sense it calls me to responsibility" (163). For education, this would entail that responsibility would not be seen as a duty (i.e. as the inverse of a right), but rather as a solicitation to support a being that is incomplete, and is to become (i.e. the student). Accompanying this what-is-to-be makes responsibility an "ethics of commitment" (164). However, Prairat is steadily led into a position of tension: whereas he presents a plea for solicitude, hospitality, as independent of a particular milieu, he understands the need to critically limit educational responsibility institutionally (unlike Levinas) (165). Prairat devises a way to address this tension between "scholastic obligation" and "educational hospitality," namely, considering educational hospitality as infusing scholastic obligation with its true meaning: "Solicitude is a kind of virtual factor which accompanies our deliberations" (166), in a context, education, marked by uncertainty.

In his research proposal, published as "L'Europe et l'infini," in Livraison et deliverance: Théâtre, politique et philosophie (Paris: Belin, 2009), 319-28, Denis Guénoun suggests that the philosophies of Levinas and Jonas could be used to explore the question concerning "Europe as the place in which a teleology of the infinite is invented and through which it flows," and that serves as a point of departure from whence to explore the "movement of auto-production of the universal" in Europe and the whole world (319). In the tense space of debate between Jonas and Levinas, both recognize the opening up of the transcendence of the good within being. The good is the opening that beckons towards the infinite. Unfortunately, Guénoun's text does not develop beyond a sketch of a hypothesis, and it is not clear whether his approach would help us to understand the relation between ethics and justice in the work of Jonas and Levinas.

A very different approach in comparing Levinas and Jonas on responsibility has been developed by Michelini. His approach is guided by his support for Apel's discourse ethics. However, one does not have to accept this conviction in order to appreciate the

\section{PHILOSOPHY TODAY}


very insightful manner in which he situates Jonas and Levinas between Weber and Apel, especially on the questions pertaining to the foundation of a responsibility that would be capable of answering for the consequences of action and that, through the discursive practice associated with it, enforces the possibility of practical and institutional deployment. Since the detailed argument of this article does not lend itself to a cursory overview, I strongly recommend the reader to consult Dorando Michelini, "Ética de la responsabilidad: Modelos de fondamentación y application," Concordia 41 (2002), 83-103. For points of comparison that are more closely related to a religious perspective on responsibility, cf. Lesch "Ethische Argumentation im jüdischen Kontext," 468-69.

36. "Pour moi, l'élément négatif, l'élément de violence dans l'État, dans la hiérarchie, apparaît même lorsque la hiérarchie fonctionne parfaitement, lorsque tout le monde se plie aux idées universelles" (Liberté et commandement, 97).

37. However, the short book Macht oder Ohnmacht der Subjektivität: Das Leib-Seele-Problem im Vorfeld des Prinzips Verantwortung (Frankfurt-am-Main: Insel Verlag, 1981) makes a contribution to a response on this issue.

38. I have developed this point further in $\S 1$ of "Responsibility in an Era of Modern Technology and Nihilism, Part 2."

39. Cf. "Transcendance, idolâtrie et secularization," in Dieu, la mort et le temps, 190-94.
40. For a discussion of Levinas's "political theology," see $\$ 5$ of my essay "The State and Politics in a PostColonial, Global Order: Reconstruction and Criticism of a Levinasian Perspective," SA Publiekreg/ Public Law 24 (2009): 352-69.

41. Cf. Levinas's phenomenology of the residence (demeure) in Totalité et infini, 162-90.

42. It is not correct to claim that Levinas's reflection on technology is limited to "Heidegger, Gagarin et nous" (Difficile Liberté, 323-27). See Adriaan Peperzak, "Technology and Nature," in Beyond: The Philosophy of Emmanuel Levinas (Evanston: Northwestern University Press, 1997), 131-144. A more comprehensive discussion is presented in my $D e$ l'éthique à la justice, 142-47 (in which the claims made in the current paragraph are worked out in detail).

43. And if individual self-sacrifice is a form of affirmation of being, it is so only because it could be a justifiable affirmation of the being of others (cf. Das Prinzip Verantwortung, 97).

44. Cf. Karl-Otto Apel, Diskurs und Verantwortung: Das Problem des Übergangs zur postkonventionellen Moral (Frankfurt-am-Main: Suhrkamp, 1988), especially chapter 6: "Verantwortung heute-nur noch Prinzip der Bewahrung und Selbstbeschränkung oder immer noch der Befreiung und Verwirklichung von Humanität?" 179-216.

45. Cf. Jean-François Lyotard, Le différend (Paris: Minuit, 1983), especially “Notice Lévinas," 163-67.

\section{ENDNOTES}

\section{University of Pretoria, Pretoria 0002, South Africa}

RESPONSIBILITY AND TECHNICS 